\title{
Dystopias Go Global: The Transnational Reorganization of Territories and Societies in Elysium \\ ABSTRACT
}

This article argues that at the turn of the twenty-first century science fiction (SF) cinema has begun to show particular interest in transnational interactions and cosmopolitan concerns. The article focuses on one of the most representative groups of this trend: dystopias that explore the transnational systems that shape deeply unequal societies. The first part of the article provides an overview of the different transnational issues that contemporary dystopias deal with. The article then presents the film Elysium (Neill Blomkamp, 2013) as a representative example of this trend. The analysis of Elysium sheds light on several socioeconomic and territorial processes that are shaping the development of neoliberal globalization in the twenty-first century: extraterritorial operations, market incorporation, and the reorganization and superposition of borders. The article concludes that Elysium and similar films at first appear to criticize a set of structures and practices that prevent large numbers of people from living in decent conditions, but eventually reproduce the same circumstances and hierarchies that they appear to denounce.

Keywords: science fiction film; globalization; cosmopolitanism; territory; borders; welfare; markets

\section{Globalizacija distopij: transnacionalna reorganizacija ozemlja in družb v filmu Elizij}

\author{
POVZETEK
}

Članek obravnava trend, ki pomembno zaznamuje znanstvenofantastično filmsko produkcijo zadnjih let, in sicer izrazito zanimanje za transnacionalne interakcije in kozmopolitsko problematiko. Študija se osredotoča na distopije, ki raziskujejo transnacionalne sisteme, odgovorne za oblikovanje skrajno neenakopravnih družb, kot eno najbolj reprezentativnih skupin tega trenda. Prvi del članka ponuja pregled različnih transnacionalnih problematik, ki jih obravnavajo sodobne filmske distopije. Sledi predstavitev filma Elizij (Neill Blomkamp, 2013) kot značilnega predstavnika tega trenda. Analiza filma Elizij osvetli številne socio-ekonomske in ozemeljske procese, ki usmerjajo razvoj neoliberalne globalizacije v 21. stoletju: ekstrateritorialne operacije, inkorporacije trgov ter reorganizacija in superpozicioniranje meja. Članek zaključuje ugotovitev, da čeprav Elizij in podobni filmi na prvi pogled kritizirajo strukture in prakse, ki večini človeštva onemogočajo solidne življenjske pogoje, se prej ko slej izkaže, da ti filmi reproducirajo pogoje in hierarhične ureditve, kot so tisti, ki jih na videz zavračajo.

Ključne besede: dobrobit; globalizacija; kozmopolizem; meje; ozemlje; trgi; znanstvenofantastični film 


\section{Dystopias Go Global: The Transnational Reorganization of Territories and Societies in Elysium}

\section{Introduction}

Dystopias have always worked as social thermometers of their time. They project grim visions of alternative (often futuristic) spaces and times to address contemporary concerns. For example, Alphaville (Jean-Luc Godard, 1965), Blade Runner (Ridley Scott, 1982), and The Terminator (James Cameron, 1984) register anxieties over the development of technology, computers and artificial intelligence; Soylent Green (Richard Fleischer, 1973) and They Live (John Carpenter, 1988) draw attention to the ever-increasing influence of large corporations and economic neoliberalism accompanying the progressive neoliberalization of the US and world economy from the 1970s onwards; and Strange Days (Kathryn Bigelow, 1995) reflects the racial tensions surrounding the 1992 Rodney King beating in Los Angeles (Grant 2013, 151-52). As these examples suggest, dystopias typically address issues such as authoritarian governments, corporate control, oppression, class/income inequality, biotechnological developments, and otherness. At the turn of the twenty-first century, a substantial number of dystopian film narratives began to add a further layer to their traditional discourses by showing greater interest in the transnational dimension of socioeconomic borders and hierarchies. Code 46 (Michael Winterbottom, 2003), Sleep Dealer (Alex Rivera, 2008), In Time (Andrew Niccol, 2011), Upside Down (Juan Solanas, 2012), the 2012 Total Recall remake (Len Wiseman, 2012), Elysium (Neill Blomkamp, 2013), Snowpiercer (Bong Joon-ho, 2013), and Jupiter Ascending (The Wachowskis, 2015) are some of the most representative examples of this emerging trend.

This article first offers an overview of the main scenarios that contemporary transnational dystopias present and then focuses on Elysium, a film that explores the workings of transnational economic structures at multiple scales. It does so by exploring some of the novel forms and roles that borders adopt and imagining geopolitical formations that offer opportunities to reflect on territorial organization, sovereignty, and welfare in the twenty-first century. Approaching Elysium from a cosmopolitan perspective, I aim to enquire into what Sandro Mezzadra and Brett Neilson call "operations of capital", that is, the logics and workings of "dispossession, exploitation, and accumulation" and also "incorporation" into the system $(2015,4-5)$. Contributing to this debate, the article discusses Elysium as a film that mirrors societies governed by neoliberal expansion and the individualization of the benefits that technological advances and modernity bring about. At the same time, the article notes the difficulties that the film finds in imagining alternative modes of socioeconomic organization.

A cosmopolitan approach to transnational dystopias can help to shed light on the technological, economic, and sociostructural changes that they present through a critical lens. As Kwame Anthony Appiah notes, cosmopolitanism is often not "the name [...] of the solution but of the challenge" (2006, xiii). Processes of economic globalization produce a range of precarious, unequal, and destabilizing circumstances that are directly related to cosmopolitan concerns. Cosmopolitan challenges are evident in contemporary realities such as transnational taxevasion, the undermining of the welfare state, public services, and worker's rights, lack of access to healthcare, extreme poverty, uneven access to resources (e.g. water), brutal re-localizations 
of capital and labour, forced mobilities, unwelcome migrations, land-grabs, and the erosion of sovereignty (see, among others, Appiah 2006, 163, 169; Beck 2006, 83-84; Papastergiadis 2012, 36-77; Mezzadra and Neilson 2013, 202-35, 245). In general, the workings of global neoliberalism affect a central dimension of cosmopolitanism: well-being and the possibility of having "decent lives" (Appiah 2006, 163, 167). As David Harvey argues, in order to imagine cosmopolitan alternatives, it is necessary to "unpack" the abstract character of neoliberal globalization and examine the actors behind it, their background, their intentions, and how they operate $(2009,57-58)$. In an attempt to do so, my analysis in this article relies heavily on geopolitical, border, and globalization theories. Such theories are crucial to unpack neoliberal globalization from a cosmopolitan perspective based on the aforementioned concerns. In this sense, the article uses cosmopolitanism in a predominantly methodological fashion.

\section{Dystopias Go Global}

Although global concerns are not exclusive to twenty-first century SF films, earlier works tend to ignore the global contexts in which they set their narratives. Films like Blade Runner, The Terminator, and The Matrix (The Wachowskis, 1999) are either set in a context of global or even galactic economic unrest or of (presumably global) totalitarian machine domination, but do not include explicit evidence of transnational connections and economic influence. Two pre-2000 exceptions to this are Rollerball (Norman Jewison, 1975) and They Live. Both films make explicit what the aforementioned works just imply: they show the role of (aspiring) global agents in the socioeconomic system. In They Live, two construction workers gradually find out that aliens, along with an elite group of humans, control the economy and manipulate citizens' perception of society. Towards the end of the film, the two workers walk into a gala dinner where a group of business people and aliens celebrate having taken over the whole US and having plans to do the same on a planetary scale by 2020. A few minutes later, a businessman tells the workers: "There ain't no countries any more. No more good guys. They're running the whole show. They [aliens] own everything. The whole goddamn planet. They can do whatever they want." Through these two moments, the film acknowledges the global aspirations of neoliberal capital. They Live - along with Rollerball - is a clear forerunner of the current tendency towards film narratives that explicitly point to the growing control of economies and societies around the world by a handful of neoliberal actors.

In the 2010s, several scholars have begun to point out the recent interest of SF cinema in migration and borders (Rivera 2012; Hamner 2015; Küchler, Maehl, and Stout 2015). However, contemporary SF cinema deals with a wider range of transnational issues. Situating their narratives in an often explicit transnational context, many twenty-first century SF films combine previous dystopian motifs such as economic exploitation, stratification, class hierarchies, and corporate control with other themes such as borders, (im)mobility, territoriality, sovereignty, transnational networks of power, capital flows, profit-making practices, and even life extraction. By addressing these topics, recent SF films often bring to the fore concerns that are central to the cosmopolitan imagination (e.g. human rights, access to resources, and social welfare).

Although little attention has been paid to these themes as recurring motifs in contemporary SF cinema, Mark Bould identifies non-places, "the dialectics of mobility and confinement," and the relationship between different kinds of labour and global capital as common concerns in contemporary SF films (2012, 184-94). Bould mentions several twenty-first century films that feature characters living in isolated spaces that range from business lounges and offices to ghettoes and refugee camps. Some of the examples that Bould gives include: Demonlover (Olivier Assayas, 
2002), Code 46, Banlieue 13/District 13 (Pierre Morel, 2004), Children of Men (Alfonso Cuarón, 2006), Eden Log (Franck Vestiel, 2007), and District 9 (Neill Blomkamp, 2009). Bould's extensive selection of films shows the prominence of borders and border-related issues in contemporary SF (84-87). Apart from focusing on borders, mobility, and lack thereof, contemporary SF films also deal with other transnational issues. Babylon A.D. (Mathieu Kassovitz, 2008), Sleep Dealer, In Time, Captain America: The Winter Soldier (Anthony and Joe Russo, 2014), Robocop (José Padilha, 2014), Elysium and again Code 46 imagine worlds in which biometrics, surveillance, and dataveillance play a key role in organizing humans within and beyond the nation state. Another sub-trend that is equally central to the analysis of globalization processes, but has attracted little attention so far, is that of films that picture alternative territorial organizations or project current territorial changes at larger scales or in an intensified manner. Code 46, Children of Men, Africa Paradis (Sylvestre Amoussou, 2006), Sleep Dealer, District 9, Captain America: The Winter Soldier, Branded (Jamie Bradshaw and Aleksandr Dulerayn, 2012), Upside Down, World War Z (Mark Forster, 2013), and Elysium consider how these territorial schemes affect normmaking, sovereignty, individual rights, spatial integration, and market expansion. In addition, they point at the extraterritorial operations of specific social actors.

In his account of some of the main concerns that SF cinema addresses, Mark Bould also notes that films such as Africa Paradis, Transformers (Michael Bay, 2007), and Sleep Dealer "illustrate the relationship between global, networked, neoliberal capitalism and the varieties of labour upon which it is built" (2012, 189). Similarly, Code 46, Eden Log, Cargo (Ivan Engler and Ralph Etter, 2009), Moon (Duncan Jones, 2009), Transfer (Damir Lukacevic, 2010), In Time, Cloud Atlas (The Wachowskis and Tom Tykwer, 2012), Upside Down, Snowpiercer, Elysium, and Jupiter Ascending constitute an additional branch of films that present systems in which those who rule society tend to take advantage of transnational or galactic asymmetries to extract value, health or even lifespan from other people's bodies, not only through physical activity, but also through the body itself, its organs or its life. These films point directly to the social implications and personal costs caused by the operations of global corporate players and the privileges that only exclusive groups enjoy. They throw light on the logics, actions, and actors of global neoliberalism. In sum, contemporary dystopias seem mainly concerned (sometimes explicitly, sometimes ambiguously and metaphorically) with geopolitical and biopolitical issues beyond national frameworks and borders.

\section{Elysium: Incorporating Markets, Bordering Benefits}

The world of Elysium provides rich opportunities for the analysis of supranational socioeconomic structures and territorial formations at several levels. Elysium imagines life in the year 2154, when the affluent elites live in a spaceship to which no-one else is allowed access. Meanwhile, the rest of humanity remains on an over-populated Earth that is running short of natural resources and whose infrastructures have severely deteriorated. In this world, borders and territories have adopted novel forms that ensure that corporate and political elites enjoy unprecedented levels of well-being while Earth inhabitants have to live in extremely precarious conditions. More specifically, the film revolves around the interactions between Los Angeles/Earth and the Elysium wheel where the elites live, and the control the latter exercise over everyone else. Through this scenario, Elysium explores what Anne Laure Amilhat-Szary and Frederic Giraut call "the superposition of vast sets of technologies of control" $(2015,2)$. In visual terms, the Elysium wheel stands out due to its dimensions, some establishing shots that direct viewers' attention towards it, and several moving aerial shots and close-ups that allow us to inspect it. The wheel and the technocultural specificities of its society are also the central conceptual elements 
of the novum that Elysium develops. Darko Suvin defines a novum as a plausible "novelty" or "innovation" that "determines the narrative logic" of the story $(1979,63)$. The wheel is indeed the greatest novelty in the system that the film depicts, as it is a new spatial formation. As such, it produces estrangement in viewers and draws attention to itself. Given the visual and narrative prominence of the wheel and the interactions that it articulates at local, planetary and galactic levels, my analysis of the film focuses on the territorial and socioeconomic reconfigurations in the futuristic and yet utterly familiar environment of the film. In the following paragraphs, I aim to show how Elysium presents different kinds of border and territorial formations as central elements in the geographical organization of global/galactic systems whose aim is to protect and foster ever-growing profits and individual privileges. ${ }^{1}$

Situating its action between Earth and its orbit, Elysium provides an eagle's eye view of current major geopolitical and economic trends on the planet. Elysium captures many of the multiple bordering processes that take place nowadays: reterritorialization and rebordering practices (Sassen 2008, 2014; Popescu 2012; Mezzadra and Neilson 2013), the networking, personalization, and mobility of borders (Walters 2004; Popescu 2012; Amilhat-Szary and Giraut 2015), and the growing use of biometrics (Amoore 2006; Popescu 2012; Potzch 2015). The film takes advantage of the privileged viewpoint that these borders offer to shape a discourse that denounces the growing socioeconomic inequalities that global capital generates. This is an aspect that Elysium shares with other recent SF movies, such as Code 46, In Time, Total Recall (2012), and Upside Down. Elysium's ability to connect current debates on borders with wider territorial and socioeconomic processes is what makes it a particularly useful film for the analysis of globalization. From a broader geopolitical perspective, Elysium engages in current debates on new international trade agreements such as TIPP or TPP and older ones such as NAFTA, the economic annexation of territories in the historical and present development of capitalism (Quijano and Wallerstein 1992; Mignolo 2000; Dickens and Ormrod 2010), the expansionist logics of neoliberalism, the proliferation of special economic zones - SEZs - (Ong 2006; Mezzadra and Neilson 2013), extraterritorial concessions (Strauss 2015), foreign land acquisitions (Sassen 2014, 80-116), and the automation and privatization of violent force (Singer 2003; McFate 2014; Varin 2015). As different as these issues may be, Elysium elucidates how they are governed by a set of neoliberal logics in which borders play a key role.

\subsection{Beyond the Fence: Dispersed, Mobile, and Embodied Borders}

Border walls feature prominently at the beginning of Elysium, as the camera flies over a fence topped with barbwire at the edges of the space wheel and an extreme long shot shows the dimensions of the fence. Yet borders do not only appear at the limits of Elysium. As Étienne Balibar notes, borders are "wherever selective controls are to be found" (2002, 84). Migrants in Elysium find borders in the homes of the space wheel, as the advanced healing beds only heal those who have an Elysium ID printed in their wrists. In addition, the robot police automatically single out those passengers whom they deem suspicious at a local bus stop. A similar scene also appears in Sleep Dealer, where a security guard uses a hand-held scanner to check passengers before they get on the bus. In this sense, borders are, as Popescu writes, "dispersed through society" $(2012,27)$. The scenario that Elysium presents may seem futuristic, yet many borders are already dispersed hundreds of miles inside and sometimes also outside national territories. Examples of this can be

Although economic expansion through the universe may seem an idea confined to the science fictional imagination, both public and private investment on projects beyond Earth is increasingly becoming part of contemporary global economic structures (see Dickens and Ormrod 2010: 531-53). This issue is addressed later on. 
found around the world. For instance, Australia processes migrants, refugees, and asylum seekers in off-shore centres outside its national territory in Bintan Island, Indonesia, or Manus Island, Papua New Guinea (Mezzadra and Neilson 2013, 167; Gibson 2015, 83). Since the drastic rise in the number of refugees who arrived in Europe in 2015 (mostly but not only because of the war in Syria), the borders of the European Union seem to have moved from countries in its edges such as Greece or Bulgaria to those well inside its territory (such as Hungary and Austria) and outside of it (such as Turkey). These countries conduct additional controls and have built new fences to manage the arrival of refugees in their territories (Castle and Surk 2015; Langley 2016). Similarly, the US Border Patrol has set up interior checkpoints up to a hundred miles (160 kilometres) away from the borders with Mexico or Canada (Ortega 2014). In this sense, Elysium reflects a global tendency towards border dispersal.

The use of drones, satellites, and the data they gather in Elysium also show that, apart from being dispersed, some borders are also mobile. ${ }^{2}$ Satellites track the course of the three unregistered shuttles that carry migrants to Elysium and, as soon as migrants land there, a Homeland helicopter carrying robot border agents comes to their location. Homeland efforts are no longer concentrated right at the border, but wherever migrants are or go. In this sense, borders move around and follow migrants. Mobile border technologies such as satellites and drones do not only facilitate Elysium's control over its territory, they also help Elysium to carry out extraterritorial actions that aim to protect its citizens and political/economic interests on foreign soil. Satellites locate the place where the shuttle of John Carlyle (William Fichtner) crashes on Earth and allow Elysium to send a group of mercenaries to fight those who plan on attacking the Elysium CEO and stealing the sensitive information that he carries in a brain-incorporated device. Satellites also reveal the identity of the protagonist, Max Da Costa (Matt Damon), as he and some other people who assault John Carlyle are identified by satellite. Later, drones manage to identify Max when he hides in the streets of Los Angeles. Satellites and drones obtain information on the go that helps Elysium's authorities to protect its territory, its privileged status and the wellbeing of its citizens almost in real time.

Elysium - like the film In Time - goes even further and suggests that borders are not only dispersed and mobile, but also embodied. Through its depiction of embodied borders, the film suggests that such lines can be anywhere and may build on other borders. Gabriel Popescu explains that since embodied borders are individual, they "allow constant and accurate movement control" (2012, 107). Embodied borders in Elysium (and often also in real life) are also biometric borders: they use a subject's unique physical or behavioural traits to establish her/his identity. Common examples of biometric markers are the iris, facial features, fingerprints, keystroke, or movement patterns (Amoore 2006, 342; Popescu 2012, 108; Potzch 2015, 105). The beds that heal citizens in the film work or not depending on the body that lies on them and are designed to only heal Elysium citizens. In order to determine whether someone is from Elysium, they read a tag that is inscribed in the patient's skin. Similarly, satellites and drones can identify Max because his biometric information is part of the database that they use. A brief glimpse of his facial features is enough for a drone to identify him. Apart from pointing to the use of physical features to sort individuals, Elysium shows that behaviours can also be used to produce information about bodies. In the film, robots acting as police and parole officers automatically read bodies: they do not only single out Max and instantaneously have access to his criminal history, but also track

Building on the work of other scholars, Gabriel Popescu notes that borders are mobile $(2012,81-82)$. The idea of mobile borders has also been recently explored by several other scholars in a volume edited by Anne-Laure Amilhat Szary and Frédéric Giraut (2015). 
and respond to his reactions (knocking him down when he uses sarcasm, or offering him a pill when his heart rate rises). The robots' reliance on such behavioural markers resonates with Holger Potzch's argument that biometrics serve to identify "abstracted patterns of life" that are deemed to require disciplining $(2015,105-6,114-15)$. As several scholars have noted, the growing use of biometric information and subsequent embodiment of the border that comes with this entails that the resulting border is wherever a human body goes (Amoore 2006, 347-48; Popescu 2012, 107; Potzch 2015, 106). Whether in their physical or behavioural form, Elysium makes clear that biometric borders are everywhere, as the information that bodies provide can be accessed and deployed wherever Max is. In general, the use of biometric information makes borders dispersed, mobile and embodied at the same time. The combination of different modalities of borders indicates that they superpose and form networks. For example, the healing beds in the film constitute a dispersed border mechanism and also depend on the embodiment of the border at a personal level through the use of biometric information.

\subsection{Reconfiguring Norms and Sovereignty}

The superposition of borders in Elysium points to three current socioeconomic processes: the reconfiguration of norms and sovereignty, market incorporation, and the individual bordering of economic benefits. To begin with, the superposition of borders allows certain actors (such as Elysium ministers and mercenaries) to skirt around sovereignty. Border policing both in the film and real world takes place beyond a nation's territory and its borders. The mercenaries are an illustrative example. One of them, Kruger (Sharlto Copley), receives an order to launch three missiles towards three "undocumented" shuttles from Earth transporting migrants headed towards Elysium. Kruger launches the missiles from Earth and, by doing so, he circumvents the planet's sovereignty. He executes an order on foreign soil, where he and Elysium would have, in theory, no authority. Even though Kruger's action is more of an extraterritorial than a crossborder shooting, this scene recalls other cross-border shootings that have occurred - among others - at the Turkey-Syria, Spain-Morocco, and US-Mexico borders during the last decade (Ortega and O'Dell 2013; Nielsen 2014; Human Rights Watch 2018). Such actions are not only criminal offences but they also disregard sovereignty. As in real life, extraterritorial/cross-border shooting is not legal in the film. Elysium officials note: "we are unauthorized to use our assets on Earth". In this case, the Elysium government calls the person who is ultimately responsible for this action - Delacourt (Jodie Foster) - to a hearing. Yet, it is a hearing without consequences for her. She keeps her political position and rebukes other government members for their "weak" approach to the protection of Elysium's borders. The only measure that the Elysium government takes is to discharge the mercenary who actually executed Delacourt's order to fire. As in the film, governments and judicial powers often allow these actions to go unchallenged, delaying investigations and eventually failing to take action against those who are supposed to see to the compliance with the law but actually break it, and trampling over the people and government of the border territory affected by such violations (Ortega and O'Dell 2013).

Sleep Dealer, Upside Down, and Captain American: The Winter Soldier present similar scenarios in which armed services deploy force on foreign soil - sometimes with the consent of local authorities - to "defend" their borders or to protect their economic interests. Upside Down shows patrol agents shooting anyone who steps into the border area that allows the inhabitants of two neighbouring planets to interact in person. The agents open fire even if those who step into this area are still in their own planet/country. Similarly, Sleep Dealer extends the range of action of the US border forces with regard to dams owned by US companies in Mexico and Colombia. The film includes 
two scenes in which drone pilots attack so-called "water terrorists", that is, those whom they deem a threat to the water company. Captain America: The Winter Soldier envisions a global surveillance system comprising satellites and military-like flying ships capable of shooting anyone who poses a threat to the economic and political powers anywhere on Earth. Elysium participates in this dialogue around extraterritorial armed forces with other contemporary SF films and develops a cosmopolitan critique of the advance of neoliberalism in terms of territorial scope.

At the same time, Elysium presents a more nuanced picture of current geopolitical trends than the aforementioned films by capturing the proliferation of private armies and mercenaries since the 1990 s, a process that has contributed to increasing the volume of private economic activity and to the consolidation of neoliberalism (Singer 2003; Tonkin 2011; McFate 2014; Varin 2015). In the film, Kruger retrieves the missiles that he is asked to launch from a container displaying the words "Elysium Corporate Authority" and "Civil Cooperation Bureau" [my emphasis], hinting that he is not part of the military. When he and two other mercenaries chase Max and his colleagues, there is nothing in their gear, equipment, or ship that links them to Elysium. Indeed, the ship carries a South African flag (a country and government that does not appear in the film), thus suggesting that these private mercenaries may have bought it from the nolonger existing (in the film) government of South Africa. In addition, Kruger's operations are not officially authorized by Elysium's government, thus recalling the covert nature of many of the operations carried out by mercenaries and private military firms in real life (Singer 2003, 48). By introducing private military actors in its narrative, the film enables a reading of military privatization as one of several steps towards the incorporation of activities that increase private sector profits. However, Elysium misses the opportunity to present these mercenaries as part of the military corporate industry, to show their role in the global economy, and their connection to finance, which according to some scholars, is a prevalent reality (Singer 2003, 47).

Production models and technologies of screening and control in Elysium show a wide network of extraterritorial economic influence designed to cater to the needs of Elysium corporations and the extreme neoliberal system in place in the film. Armadyne is a company managed by an Elysium citizen - John Carlyle - and it manufactures its products (robots) for the orbiting community. The government of the space wheel then decides how to deploy the robots both on Earth and Elysium. The large dimensions of the facility and the workers' precarious conditions point to Armadyne's resemblance to a maquiladora or a factory in an SEZ (special economic zone) - both examples of extraterritorial concessions. As Michael Strauss points out, extraterritorial concessions consist of a company or country operating activities in a delimited area on foreign soil in which special norms or laws apply $(2015,63)$. He also notes that "a leased territory can be a potential target of military attack" $(2015,66)$. Armadyne adopts security measures such as scanning workers to ensure that they do not carry any weapons into the factory. This suggests that Armadyne is an extraterritorial concession. A similar way of depicting an extraterritorial concession appears in Sleep Dealer, where armed guards, automatic firearms, and drones protect dams owned by US capital in Colombia and Mexico. Extraterritorial concessions such as SEZs in China, India, Latin America, some African countries (often with China as a mediator) or maquiladoras in Mexico adapt their national legal framework to specific areas so that companies may benefit from a set of norms that meet their needs (Ong 2006, 19, 77, 106; Mezzadra and Neilson 2013, 216-17). In this sense, corporations indirectly alter legislation to suit their interests. Elysium's power to alter norms is also evident in its ability to designate Los Angeles as a no-fly zone as the community see fit, temporarily banning any flights to or from the city. Such configurations indicate that Elysium reconfigures norms at its will and evince the malleability of Earth's sovereignty. 


\subsection{Territorial Integration and Market Incorporation}

Elysium also presents a world of territorial and economic integration. Even though it focuses on a specific area - a sprawling LA in ruins - the film suggests that this represents the state of most of the planet. This is evident from the very first shots. Elysium opens with a series of aerial tracking shots that show several identical sprawling urban areas in decay. The speed of these shots, the substantial range of space that they cover, and the almost-identical landscapes that they show indicate that the view they offer is a generalized reality. In addition, the captions that accompany these initial shots introduce the film's geographical premise by referring to Earth as a whole. The fact that the parts set in LA were actually shot near Mexico City and that LA visually recalls, as Celestino Deleyto points out, a "Middle East war-wrecked town" (2013), also contribute to the effect of making this fictional LA look as if it could be set almost anywhere on Earth. After these glimpses of urban spaces, an establishing shot of the planet suggests that Earth has become a single territory. The film further reinforces this image of a unified global space through additional establishing shots of urban areas in decay without specifying their location at different points in the film.

Such territorial integration on Earth, along with Elysium's extraterritorial power, indicate that Elysium has set up a large-scale project of economic extraction in which those who live in the space station benefit from the generation of value from Earth as a whole. Free trade with Earth satisfies one of the biggest concerns for Elysians (apart from border security): to maximize revenue. In a conversation with Armadyne CEO John Carlyle, other managers show their concern that "a clear path to upside" (to higher profits) may be compromised. Relying on different narrative techniques, other SF films such as They Live and Jupiter Ascending have shown similar cosmopolitan concerns by having civilizations from distant planets come to Earth to incorporate its economic activity into their system. Similar market enlargement and integration patterns are taking place in the world right now, both at private and national levels. A clear example from the private sector is Apple. On October 27, 2015, the company presented the largest annual corporate profits in history (\$53.4 billion), mostly thanks to its sales in the Chinese market (News Corp Australia 2015). In general, such results depend on a constant renegotiation of norms to allow companies to penetrate markets with ever more advantageous conditions.

Apart from trade and market integration agreements in place such as NAFTA and the one regulating the European Economic Area, several national governments are trying to develop similar agreements at an even larger scale. Two of the most prominent examples are the TransPacific Partnership (TPP), which currently includes Australia, Brunei, Canada, Chile, Japan, Malaysia, Mexico, New Zealand, Peru, Singapore, and Vietnam, and the Transatlantic Trade and Investment Partnership (TTIP) between the USA and European Union. Although the Trumpled US government has recently retreated from the TPP and put the TTIP on hold, it is likely that the US will join these or similar deals in the future (Rappeport 2018). Before the United States' current position, these agreements entailed a major leap in scope. The TTIP and the TPP were forecast to regulate economic zones that account for $50 \%$ and $40 \%$ of the world's GDP respectively. Together, however, they were expected to comprise $60 \%$ of the world's GDP, as the US initially participated in both agreements (Oxford Analytica 2014). These agreements guarantee an easier mobility of capital and goods, but do not envisage the free mobility of people, nor do they protect their welfare. TTIP creates advantageous normative frameworks for transnational business players, giving them a say in public policy-making and granting them the right to sue governments if their policies harm their profits - however beneficial such policies 
may be for the environment or society (Strange 2015, 86; De Ville and Siles-Brügge 2016, 130 31 ). In short, such agreements seek to expand the scope of corporate power and profits. While the idea of a homogeneous, completely-integrated Earth that Elysium sketches is deceiving, it hints at the role of scale in the current development of neoliberalism.

The current trend towards the enlargement of the scope of economies by territorial means that Elysium presents is not entirely new: it is part of a larger historical context of territorial incorporation that is likely to keep developing in the future, as the film suggests. Aníbal Quijano and Immanuel Wallerstein argue that the Americas were essential in the growth and establishment of the modern world-system, which they trace back to the 16th century. They note that one of the key factors in the development of the world-system was that the Americas provided a large extension of land (1992, 549-50). Similarly, Walter Mignolo observes that the first Christian mission that incorporated the Americas into a world-system subsequently gave way to what he calls the civilizing, developmental, and neoliberal missions (2000, 724-25), all of which have been ways of reorganizing world geopolitics to expand the economic scope and influence of capital-hoarding elites. Opportunities for profit enlargement are not limited to Earth: Peter Dickens and James Ormrod have noted the relevance of outer space in current economic systems and its central role in future economic growth. In their work on the expansion of the economy, Dickens and Ormrod point to current realities such as the role of satellites in the functioning of communication systems and their relevance in sectors such as the media and finance (2010, 533-34). They also mention plans for expanding the tourism industry in outer space and the economic potential of setting mines on other planets and finding new ways of using solar energy in space $(2010,535,541)$. Elysium captures this ongoing development of the neoliberal mission in outer space through the spatial concept that governs the narrative, by filtering some events through satellite information screens, and through the camerawork that the film uses to present the space station. This last aspect is evident in an establishing shot at the beginning of the film in which the camera pans from Earth to the Elysium wheel as the music increases slightly in volume. Apart from showing the location of a new economic frontier, this shot captures the radical expansion of the system in a visual and aural way.

\section{Elysium's Ambivalent Cosmopolitanism}

The expansion, integration, and accumulation processes described above are accompanied by the bordering of the profits and benefits that Elysium generates (a clean environment, advanced technologies, fast transportation, comfort, leisure, premium healthcare). Of all these benefits, the film puts special emphasis on access to health treatments and the de-bordering of this 'privilege' at the end of the story. Elysium juxtaposes an overcrowded and deteriorated hospital with scarce resources in LA with the individual healing beds that every Elysium citizen seems to have at home. Advanced technologies also check health risks and life threats for Elysians and provide them with instant information about their health anywhere on Earth or the space station. For example, when John Carlyle's shuttle crashes in LA, a computer lets him know that he is not harmed and provides Elysium with updates on his condition. The dispersed, embodied, mobile, and extraterritorial character of borders guarantees restricted access to such Elysian privileges while allowing the expansion of borderlands and of the neoliberal economic system that Elysium relies on. The film suggests that borders do not only delimit (rich) countries but also protect the individual property, benefits, and security that a few enjoy. When a shuttle with migrants heads towards the space station, Elysians treat it as a "security breach". This breach does not pose a violent threat for Elysians, but rather threatens their privatized and personalized security (which 
reflects a reversal of the social security schemes that some countries built in the second half of the twentieth century, and are now being privatized and thus, individualized). The film reflects what William Walters, in his analysis of British security policies, calls the "reordering and [...] re-hierarchizing of political priorities" in favour of border security and to the detriment of social welfare $(2004,244)$. Elysians deem the inclusion of more citizens an obstacle to the growth of their income and privileges. In the hidden logics of this system, more people equals less share. However, at the end of the film, Max and Spider (Wagner Moura) - the leader of the gang that sends the shuttles to Elysium - hack Elysium's computer and reset it so that everyone on Earth counts as an Elysium citizen. By doing so, they de-border Elysium's health privileges. Some of the last shots show people of different ethnicities running towards medical shuttles sent to Earth. Thus, the film celebrates the cosmopolitan ideal of global access to decent healthcare.

However, even though Elysium appears to develop a cosmopolitan discourse through its celebration of universal healthcare and its critical portrayal of borders, extraterritorial operations, and market incorporation, it is more ambiguous in other respects. The ending hints that the divide between both worlds vanishes as every person on Earth gets Elysium citizenship and access to healthcare. Without doubt, healthcare is an important issue, but it does not guarantee the creation of a series of circumstances that allow people to have a decent life (although it contributes to it). In spite of the changes that occur at the end of the film, a gulf still exists between the former citizens of Elysium and those who live in resource-depleted areas, those who have poor job conditions or do not even have a job, and presumably also other groups who do not explicitly appear in the film, such as the homeless and families without income. At the end of the film, the systemic circumstances that lead most people to live in shanty towns and subsist through informal economic activities do not change. Although the different borders in Elysium disappear or weaken, the film's ending overlooks the central role of the economic model (extraterritorial concessions, market integration and expansion, corporate cultures of profit maximization, and resource exploitation) in creating the harsh life conditions that most people on Earth endure throughout the narrative. Echoing Giorgio Agamben, the authors of "The antiAtlas of Borders, A Manifesto" note that "neoliberal thinking [...] sees addressing the root causes of various issues as more costly than dealing with their effects" (Parizot et al. 2014, 3). This is precisely what Elysium's ending does: it presents the mitigation of some effects of Elysium's neoliberal economic practices (the lack of healthcare) as a solution for people on Earth. It proposes a patch on the system rather than its reformulation. Elysium also reflects what Mark Fisher calls "capitalist realism": the inability to imagine alternatives to neoliberalism $(2009,2)$. Conforming to this notion, Elysium generates contradictions and makes the alternative (a global healthcare scheme) part of the mainstream (a savage neoliberal system) (Fisher 2009, 5, 9). In the end, Elysium's cosmopolitan dreams fall prey to the capitalist-realist environment that permeates contemporary life.

Finally, another aspect that contributes to the ambivalent character of Elysium is the role of race in the film. Elysium includes characters of different ethnicities: LA is a largely Latino area where some Spanish can be heard; the "undocumented" shuttles that travel towards Elysium carry Asian, Latino, and black characters; Carlyle has a video call with other managers who are a black man, a blonde Anglo woman, and an Asian man; and the last name of Elysium's Prime Minister is Patel, suggesting that he is of Indian descent. Yet, except for the nurse Frey (Alice Braga), Max's friend Julio (Diego Luna), and perhaps also Spider, most of the main characters (Max, Delacourt, Carlyle, Kruger) are white. More importantly, the end of the film emphasizes Max's role as a Christ-like (and white) saviour, pushing other racial and systemic debates to the side. In this sense, Elysium develops a similar racial discourse to The Matrix. Nicola Rehling 
observes that "despite the trilogy's obvious effort to include a multicultural cast [...], Western racial norms are reinscribed" by presenting Neo as a white messiah $(2009,126)$. In one of the last scenes of Elysium, Max gives his life - that is, he dies - so that the rest of humanity may be granted citizenship and have access to healthcare. The last moments of the film pay tribute to Max's heroism by recreating some moments from his childhood. Previously, the film celebrates universal healthcare through several shots of non-white people running towards the health shuttles that are landing on Earth. The inclusion of moments from Max's childhood shifts attention from the actual changes that the world is about to go through to focus on the white saviour. In fact, the very last shot of the film is an image of Max as a kid running on the street as a thin halo of light glows in the middle of the frame. In addition, the shuttles and robots that come to heal people are also white, and their colour fills the frame in several of the last shots. Although white is a colour that is commonly used in medical contexts, such whiteness is non-existent in the LA hospital that appears earlier in the film. These images thus reinforce the image of the white saviour and the strong dichotomy between the whiteness of the saviours and the blackness of the saved, a trope that Matthew Hughey has identified as a common practice in cinema $(2014,2)$. In spite of the potential that Elysium has shown for the analysis of contemporary global phenomena from a cosmopolitan perspective, the film fails not only to imagine systemic reinvention, but also to envision non-whites participating in the construction of their future.

\section{Conclusion}

Elysium shows that governmental and corporate actors defend private economic interests by establishing systems of superposed borders, reconfiguring norms, and skirting around sovereignty. In addition, the film's imagined geography captures contemporary processes of territorial integration, market incorporation, and profit maximization. However, Elysium's elites do not only enjoy the privilege of accumulating capital: they use their economic and political power to enjoy a series of benefits (excellent healthcare, fast transportation, leisure, an unpolluted environment, and technological advances) for themselves. That is, they border the benefits of technocultural modernity. Despite the critical character of this scenario, Elysium offers an ambivalent position towards borders and cosmopolitan possibilities. On the one hand, the film exposes an exploitative socioeconomic system that operates at multiple geographical scales. On the other, it perpetuates racial boundaries and proposes patches to the aforementioned global designs rather than a revision of the function of borders and substantial systemic reform. This cosmopolitan ambivalence is not exclusive to Elysium. Other recent science fiction films such as Avatar (James Cameron, 2009), 2012 (Roland Emmerich, 2009), Cloud Atlas, and The Host (Andrew Niccol, 2013) also develop ambivalent narratives that offer easy solutions for complex transnational challenges, avoid tackling thorny cultural conflicts, celebrate attitudes of openness towards Others who are not really alien or different, or simply end up privileging white characters. Beyond the scope of science fiction, María del Mar Azcona has also argued that Matt Damon's star persona is imbued with cosmopolitan ambivalence $(2018,7-12)$. In this sense, Elysium participates in a wider cinematic discourse that envisions cosmopolitan alternatives to systems of transnational exploitation and discrimination and simultaneously reinforces the social structures and practices that prevent cosmopolitan possibilities from developing. 


\section{Acknowledgements}

I would like to thank Celestino Deleyto for his comments on an earlier version of this article. Research towards this article has been funded by a PhD fellowship from the Spanish Ministry of Education, Culture, and Sport; research project no. FFI2013-43968-P of the Spanish Ministry of Economy and Competitiveness; and research project no. H12 of the Government of Aragón.

\section{References}

Amilhat-Szary, Anne Laure, and Frédéric Giraut. 2015. "Borderities: The Politics of Contemporary Mobile Borders." In Borderities and the Politics of Contemporary Mobile Borders, edited by Anne Laure AmilhatSzary and Frédéric Giraut, 1-22. London: Palgrave Macmillan.

Amoore, Louise. 2006. "Biometric Borders: Governing Mobilities in the War on Terror." Political Geography 25 (3): 336-51. https://doi.org/10.1016/j.polgeo.2006.02.001.

Appiah, Kwame Anthony. 2006. Cosmopolitanism: Ethics in a World of Strangers. London: Penguin.

Azcona-Montoliu, María del Mar. 2018. "Matt Damon: A Cosmopolitan Hero for the Mainstream." Celebrity Studies, March 13, 2018. https://doi.org/10.1080/19392397.2018.1445536.

Balibar, Étienne. 2002. Politics and the Other Scene. London and New York: Verso.

Beck, Ulrich. 2006. The Cosmopolitan Vision. Cambridge: Polity.

Bould, Mark. 2012. Science Fiction. London and New York: Routledge.

Castle, Stephen, and Barbara Surk. 2015. "Migrants Diverted to Slovenia After Hungary Closes Border." The New York Times, October 17, 2015. http://www.nytimes.com/2015/10/18/world/europe/hungary-closesborder-changing-refugees-path.html?hp\&action=click\&pgtype=Homepage\&module=second-columnregion\&region=top-news\&WT.nav=top-news.

De Ville, Ferdi, and Gabriel Siles-Brügge. 2016. The Truth about the Transatlantic Trade and Investment Partnership. Cambridge and Malden, MA: Polity.

Deleyto, Celestino. 2013. "The Beauty of the Gated Community." Cinema, Culture and Society. http://ccs. filmculture.net/ccsblog/139-the-beauty-of-the-gated-community.

Dickens, Peter, and James Ormrod. 2010. "Globalization of Space: From the Global to the Galactic." In The Routledge International Handbook of Globalization Studies, edited by Bryan Turner, 531-53. Abingdon, OX and New York: Routledge.

Fisher, Mark. 2009. Capitalist Realism: Is There No Alternative? Winchester and Washington: Zero Books.

Gibson, Suzie. 2015. "Stop the Ships: 'Elysium', Asylum Seekers and the Battle over Sovereign Borders." Screen Education 78: 78-85.

Grant, Barry Keith. 2013. 100 Science Fiction Films. London: Palgrave Macmillan.

Hamner, Everett. 2015. "Virtual Immigrants: Transfigured Bodies and Transnational Spaces in Science Fiction Cinema." In Simultaneous Worlds: Global Science Fiction Cinema, edited by Jennifer Feeley and Sarah Ann Wells, 154-70. Minneapolis: Minnesota University Press.

Harvey, David. 2009. Cosmopolitanism and the Geographies of Freedom. New York: Columbia University Press.

Hughey, Matthew. 2014. The White Savior Film: Content, Critics, and Consumption. Philadelphia: Temple University Press. 
Human Rights Watch. 2018. “Turkey/Syria: Border Guards Shoot, Block Fleeing Syrians.” Human Rights Watch, February 3, 2018. https://www.hrw.org/news/2018/02/03/turkey/syria-border-guards-shoot-blockfleeing-syrians.

Küchler, Ulrike, Silja Maehl, and Graeme Stout. 2015. "Introduction.” In Alien Imaginations: Science Fiction and Tales of Transnationalism, edited by Ulrike Küchler, Silja Maehl, and Graeme Stout, 1-12. New York and London: Bloomsbury.

Langley, Alison. 2016. "Austria Streamlines Slovenia Border to Process Refugees.” Deutsche Welle, January 22, 2016. http://www.dw.com/en/austria-streamlines-slovenia-border-to-process-refugees/a-18999606.

McFate, Sean. 2014. The Modern Mercenary: Private Armies and What They Mean for World Order. Oxford and New York: Oxford University Press.

Mezzadra, Sandro, and Brett Neilson. 2013. Border as Method, or, the Multiplication of Labor. Durham and London: Duke University Press.

—. 2015. “Operations of Capital.” South Atlantic Quarterly 114 (1): 1-9.

Mignolo, Walter. 2000. “The Many Faces of Cosmo-polis: Border Thinking and Critical Cosmopolitanism.” Public Culture 12 (3): 721-48.

News Corp Australia. 2015. "Apple Reports Biggest Annual Profit in Corporate History." News.com. au, October 28, 2015. http://www.news.com.au/finance/business/technology/apple-reports-biggestannualprofit-in-corporate-history/news-story/0a9c0a51d94b85cd2149b3a1cc013c39.

Nielsen, Nikolaj. 2014. "EU Wants Investigation into Spanish Border Guard Shootings.” EU Observer, February 14, 2014. https://euobserver.com/justice/123151.

Ong, Aihwa. 2006. Neoliberalism as Exception: Mutations in Citizenship and Sovereignty. Durham, NC: Duke University Press.

Ortega, Bob. 2014. “Border Patrol Checkpoints Stir Public Backlash.” USA Today, June 7, 2014. http://www. usatoday.com/story/news/nation/2014/06/07/border-patrol-checkpoints-stir-public-backlash/10113693/.

Ortega, Bob, and Rob O'Dell. 2013. "Deadly Border Agent Incidents Cloaked in Silence." The Arizona Republic, December 16, 2013. http://www.azcentral.com/news/politics/articles/20131212arizona-borderpatrol-deadly-force-investigation.html.

Oxford Analytica. 2014. "International Trade Partnerships: Deal or No Deal?” Oxford Analytica, July 31, 2014. http://www.oxan.com/analysis/dailybrief/samples/InternationalTradeTreaties.aspx?WT.mc_id=TWT.

Papastergiadis, Nikos. 2012. Cosmopolitanism and Culture. Cambridge and Malden, MA: Polity.

Parizot, Cédric, Anne-Laure Amilhat Szary, Gabriel Popescu, Isabelle Arvers, Thomas Cantens, Jean Cristofol, Nicola Mai, Joana Moll, and Antoine Vion. 2014. "The antiAtlas of Borders, A Manifesto." Journal of Borderlands Studies 29 (4): 503-12. https://doi.org/10.1080/08865655.2014.983302.

Popescu, Gabriel. 2012. Bordering and Ordering the Twenty-First Century: Understanding Borders. Lanham, MD: Rowman and Littlefield.

Potzch, Holger. 2015. “The Emergence of iBorder: Bordering Bodies, Networks, and Machines." Environment and Planning D: Society and Space 33: 101-18. https://doi.org/10.1068/d14050p.

Quijano, Aníbal, and Immanuel Wallerstein. 1992. "Americanity as a Concept, or the Americas in the Modern World-System.” International Social Science Journal 29: 549-57.

Rappeport, Alan. 2018. "Mnuchin Floats Rejoining Trans-Pacific Partnership, Trade Deal Trump Shelved." The New York Times, February 27, 2018. https://www.nytimes.com/2018/02/27/us/politics/mnuchin-tpptrans-pacific-partnership-trump.html.

Rehling, Nicola. 2009. “Terminal Bodies and Cartesian Trips: White Heterosexual Masculinity in 
Cyberfantasies." In Extra-Ordinary Men: White Heterosexual Masculinity and Contemporary Popular Cinema, 115-36. Plymouth: Lexington Books.

Rivera, Lysa. 2012. "Future Histories and Cyborg Labor: Reading Borderlands Science Fiction after NAFTA.” Science Fiction Studies 39 (3): 415-36. https://doi.org/10.5621/sciefictstud.39.3.0415.

Sassen, Saskia. 2008 (2006). Territory, Authority, Rights: From Medieval to Global Assemblages. Princeton and Oxford: Princeton University Press.

-. 2014. Expulsions: Brutality and Complexity in the Global Economy. Cambridge, MA: Harvard University Press.

Singer, P. W. 2003. Corporate Warriors: The Rise of the Privatized Military Industry. Ithaca and London: Cornell University Press.

Strange, Michael. 2015. "Implications of TTIP for Transnational Social Movements and International NGOs." In The Politics of Transatlantic Trade Negotiations: TTIP in a Globalized World, edited by JeanFrédéric Morin, Tereza Novotná, Frederik Ponjaert, and Mario Telò, 81-92. Farnham and Burlington, VT: Ashgate.

Strauss, Michael. 2015. "Nations Outside Their Borders: How Extraterritorial Concessions Reinforce Sovereignty." In Borderities and the Politics of Contemporary Mobile Borders, edited by Anne Laure AmilhatSzary and Frédéric Giraut, 53-67. London: Palgrave Macmillan.

Suvin, Darko. 1979. Metamorphoses of Science Fiction: On the Poetics and History of a Literary Genre. New Haven and London: Yale University Press.

Tonkin, Hannah. 2011. State Control over Private Military and Security Companies in Armed Conflict. Cambridge: Cambridge University Press.

Varin, Caroline. 2015. Mercenaries, Hybrid Armies, and National Security. Abingdon, OX and New York: Routledge.

Walters, William. 2004. "Secure Borders, Safe Haven, Domopolitics.” Citizenship Studies 8 (3): 237-60. https://doi.org/10.1080/1362102042000256989. 